\title{
マグネシウム塩を含有する石灰・セメント処理 土の強度発現および海水環境下での劣化速度
}

\author{
原 弘行 1 -末次 大輔 2 - 松田 博 3 - 亀井 健史 4 \\ 1正会員 宮崎大学助教 工学部社会環境システム工学科（†889-2192 宮崎市学園木花台西1-1） \\ E-mail: hara-h@cc.miyazaki-u.ac.jp \\ 2正会員 佐賀大学准教授 低平地沿岸海域研究センター（广840-8502 佐賀市本庄町1番地） \\ E-mail: suetsugu@ilt.saga-u.ac.jp \\ 3正会員 山口大学教授 大学院理工学研究科（干755-8611 山口県宇部市常盤台2-16-1） \\ E-mail: hmatsuda@yamaguchi-u.ac.jp \\ 4正会員 宮崎大学教授 工学部社会環境システム工学科（†889-2192 宮崎市学園木花台西1-1） \\ E-mail: kamei@civil.miyazaki-u.ac.jp
}

\begin{abstract}
石灰やセメントを混合した地盤の強度発現には種々の要因が関係しており，とくに粘土鉱物の種類や間 隙水の性質によっては著しく強度発現が阻害される場合がある. 本研究では, マグネシウム塩を含む粘性 土試料を母材とした石灰・セメント処理土の強度特性を調べるため, マグネシウム塩の濃度を変化させた 処理土に対して一軸圧縮試験を実施した。つぎに, 同様の処理土に対して海水環境を想定した劣化促進実 験を行い, 力学的劣化の進行に及ぼすマグネシウム塩の影響を考察した. その結果, 処理土内のマグネシ ウム塩は強度発現を阻害するとともに, 劣化の進行を促進させることを示した. また, 固化処理土に含ま れる酸化カルシウム量とそのマグネシウム塩との比率に着目し, 固化材の種類に依存しない劣化速度の評 価指標を提案した.
\end{abstract}

Key Words : quick lime, blast-furnace slag cement type B, magnesium salts, solidification inhibition, deterioration rate

\section{1. はじめに}

石灰やセメントを土に混合寸る固化処理工法は，対象 地盤の性質によっては強度発現が阻害されることがよく 知られている. 現在までに固化処理土の強度発現を阻害 する要因として，フミン酸やフルボ酸に代表される腐植 酸(例えば゚火山灰質粘性土に多く含まれる粘土鉱物のア ロフェン例ネ゙2゙の影響等が報告されている.

一方，近年酸化マグネシウム（MgO）を主原料とし た地盤改良用固化材（以下，Mg系固化材）の開発が進 められている. Mg系固化材はセメント等に比べて低 $\mathrm{pH}$ 域で強度改善を図ることができ ${ }^{3)}$ ，かつ大きな重金属の 不溶化効果を発揮する年特徴を持っている. しかしなが ら，沖積粘土のような軟弱地盤を対象としたとき，従来 のセメント系固化材と比較して改良効果が低い場合も報 告されており ${ }^{3}$ ，Mg系固化材と石灰・セメント系固化材 を併用する技術開発も検討されているが，このとき強度 発現が著しく抑制される場合が指摘されているす)，石
灰・セメント処理土は海水に含まれるMg塩の浸透によ ってカルシウム成分の溶出が促進され, 力学的劣化に至 ることがこれまでに明らかにされておりの，上記の腐植 酸やアロフェンと同様にMg成分についても石灰・セメ ント処理工法による改良効果を阻害する可能性が示唆さ れている. 以上のような既往の報告例より，海成粘土の ように間隙水に $\mathrm{Mg}$ 塩が含まれる地盤を石灰やセメント で固化処理する場合には, 処理土の強度発現の阻害や, それに起因して海水環境下での劣化の進行を促進させる ことが推定される.

本研究では, Mg塩の濃度を変化させた粘性土を母材 とする石灰・セメント処理土に対して一軸圧縮試験およ び海水環境下での劣化速度を調べる浸漬実験を行い, $\mathrm{Mg}$ 塩を含む固化処理土の強度発現ならびに海水環境下 での劣化速度について検討した. 
表-1 試料土の物性

\begin{tabular}{lll}
\hline 土粒子の密度 & $\left(\mathrm{g} / \mathrm{cm}^{3}\right)$ & 2.60 \\
\hline 液性限界 & $(\%)$ & 98.0 \\
\hline 塑性限界 & $(\%)$ & 34.2 \\
\hline 粒度組成 & $(\%)$ & \\
$\quad$ 礫 & & 0.0 \\
砂 & & 3.0 \\
シルト & & 34.0 \\
粘土 & & 63.0 \\
\hline
\end{tabular}

表-2 固化材の $\mathrm{CaO}$ 含有率

\begin{tabular}{cc}
\hline 固化材 & $\mathrm{CaO}$ 含有率 $C_{\mathrm{CaO}}(\%)$ \\
\hline $\begin{array}{c}\text { 高炉セメント } \\
\text { (BB) }\end{array}$ & 54.49 \\
$\begin{array}{c}\text { 生石灰 } \\
\text { (QL) }\end{array}$ & 96.89 \\
\hline
\end{tabular}

\section{2. 供試体の作製方法}

\section{（1）供試体作製に用いた材料}

試料土には，北九州粘土を用いた，試料土の物性を表 -1に示す．固化材には生石灰 $(\mathrm{QL})$ と高炉セメントB種 (BB)を用いた.

海水には，硫酸マグネシウム $\left(\mathrm{MgSO}_{4}\right)$ と塩化マグネ シウム $\left(\mathrm{MgCl}_{2}\right)$ の2種のマグネシウム $(\mathrm{Mg})$ 塩が含ま れている》. 式(1), (2)に示すように，どちらも同じ比率で 処理土中の水酸化カルシウム $\left(\mathrm{Ca}(\mathrm{OH})_{2}\right)$ と反応し，か つ同様な反応が生じる8

$$
\begin{aligned}
& \mathrm{MgSO}_{4}+\mathrm{Ca}(\mathrm{OH})_{2} \rightarrow \mathrm{Mg}(\mathrm{OH})_{2}+\mathrm{CaSO}_{4} \cdot 2 \mathrm{H}_{2} \mathrm{O} \\
& \mathrm{MgCl}_{2}+\mathrm{Ca}(\mathrm{OH})_{2} \rightarrow \mathrm{Mg}(\mathrm{OH})_{2}+\mathrm{CaCl}_{2}
\end{aligned}
$$

本研究では， $\mathrm{MgSO}_{4}$ を選択し，硫酸マグネシウム7水和 物 $\left(\mathrm{MgSO}_{4} \cdot 7 \mathrm{H}_{2} \mathrm{O}\right)$ の試薬（以下 $\mathrm{MgSO}_{4}$ 試薬）を使用し て試料土のMg塩の濃度を調整した。

\section{（2）試料土のマグネシウム塩の濃度調整}

$\mathrm{QL}, \mathrm{BB}$ 両固化材に含まれる酸化カルシウム $(\mathrm{CaO})$ は土中の水と反応し, 式(3)に示寸消化反応によって水 酸化カルシウム $\left(\mathrm{Ca}(\mathrm{OH})_{2}\right)$ が生成される9.

$$
\mathrm{CaO}+\mathrm{H}_{2} \mathrm{O} \rightarrow \mathrm{Ca}(\mathrm{OH})_{2}+109 \mathrm{~kJ} / \mathrm{mol}
$$

さらに, $\mathrm{Ca}(\mathrm{OH})_{2}$ は $\mathrm{MgSO}_{4}$ と式(1)で示した化学反応を起 こし，水酸化マグネシウム $\left(\mathrm{Mg}(\mathrm{OH})_{2}\right)$ と硫酸カルシウ 么2水和物 $\left(\mathrm{CaSO}_{4} \cdot 2 \mathrm{H}_{2} \mathrm{O}\right)$ が生成される。 したがって, 土中の $\mathrm{CaO} と \mathrm{MgSO}_{4}$ は1対1の比率で反応する.

ここで，表-2に示す本研究で用いた固化材（QL, BB） の $\mathrm{CaO}$ 含有率と次節で述べる固化材添加量によって, 式 (4)から単位体積当たりの $\mathrm{CaO}$ の物質量N $\mathrm{CaO}$ を算出する.

$$
N_{\mathrm{CaO}}=\frac{\alpha \cdot C_{\mathrm{CaO}} / 100}{M_{\mathrm{CaO}}} \times 1000
$$

ここに， $N_{\mathrm{CaO}}$ は単位体積当たりの $\mathrm{CaO}$ の物質量 $\left(\mathrm{mol} / \mathrm{m}^{3}\right)$, $\alpha$ は固化材添加量 $\left(\mathrm{kg} / \mathrm{m}^{3}\right) ， \mathrm{CaO}_{\mathrm{a}}$ は固化材の $\mathrm{CaO}$ 含有率 （\%)，McaoはCaOのモル質量 $(56.08 \mathrm{~g} / \mathrm{mol} ）$ を表す.

同様にして, 試料土に添加寸る $\mathrm{MgSO}_{4}$ の単位体積当た りの物質量 $N_{\mathrm{Mgs} O 4}$ は次式より求められる.

$$
N_{\mathrm{MgSO}_{4}}=\frac{\beta}{M_{\mathrm{MgSO}_{4}}} \times 1000
$$

ここに， $N_{\mathrm{MgSO} O 4}$ は単位体積当たりの $\mathrm{MgSO}_{4}$ の物質量 $\left(\mathrm{mol} / \mathrm{m}^{3}\right) ， \beta$ は $2 \mathrm{MgSO}_{4}$ 添加量 $\left(\mathrm{kg} / \mathrm{m}^{3}\right) ， \mathrm{M}_{\mathrm{MgSO}_{4}}$ は $\mathrm{MgSO}_{4}$ のモル質量（120.38 g/mol）を表す．試料土のMg塩の濃 度は上記 $N_{\mathrm{GaO}}, N_{\mathrm{MgSO} 4}$ の比，すなわち試料土に添加する $\mathrm{CaO}$ に対する $\mathrm{MgSO}_{4}$ のモル比を $M / C$ と定義し, これが目 標の数值となるように式(5)中の $\beta$ を求め, $\mathrm{MgSO}_{4}$ 試薬の 添加量を決定した.

\section{（3）供試体作製手順}

試料土は固化材と均一に混合するために含水比を液性 限界の1.5倍に調整して使用した．固化材の添加量は, QLの場合 $50 \mathrm{~kg} / \mathrm{m}^{3}$ ，BBの場合 $70 \mathrm{~kg} / \mathrm{m}^{3}$ とした。 $M / C$ は $0,5,10$, 20,50\%となるようにした.

含水比調整後の試料土に対してMgSO試薬を加えて混 合した後，固化材を添加して電動ミキサーで10分間擋汼

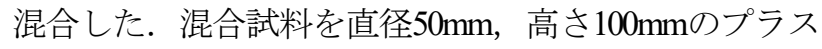
チックモールドに空気が入らないようにタッピングしな がら充填した．このとき，養生期間中の酸化を防ぐため に余盛してフィルムを被せて温度 $20^{\circ} \mathrm{C}$, 湿度 $80 \%$ に調整 した恒温恒湿器内で養生を行った３章で述べる一軸圧 縮試験には7日間および28日間養生した供試体を用いた。 また，4章の劣化促進実験には28日間養生した供試体の みを用いた，供試体の作製条件を表-3にまとめて示す.

\section{3. マグネシウム塩を含有する固化処理土の一軸 圧縮強さ}

\section{(1) 実験方法}

7,28日間養生した各 $M / C$ /供試体に対して一軸圧縮試 験を実施した．試験はJISA1216「土の一軸圧縮試験方法」 に準拠して行った.

\section{(2) 実験結果}

生石灰 (QL) , 高炉セメントB種（BB）で固化処理し た供試体の一軸圧縮強さと $M / C$ /関係を図-1に示寸。両 処理土とも同じM/Cの場合では，7日養生供試体よりも 
表-3 供試体の作製条件

\begin{tabular}{|c|c|c|c|}
\hline \multicolumn{2}{|c|}{ 試料土の含水比 $w$} & $(\%)$ & 147.0 (=1.5m) \\
\hline 固化材添加量 & QL & \multirow{2}{*}{$\left(\mathrm{kg} / \mathrm{m}^{3}\right)$} & 50 \\
\hline$\alpha$ & BB & & 70 \\
\hline \multicolumn{2}{|l|}{ 供試体寸法 } & $(\mathrm{mm})$ & $\phi=50, H=100$ \\
\hline \multicolumn{2}{|c|}{$\begin{array}{c}\mathrm{CaO} \text { と } \mathrm{MgSO}_{4} \text { のモル比 } \\
M / C\end{array}$} & $(\%)$ & $0,5,10,20,50$ \\
\hline \multicolumn{2}{|c|}{ 養生期間 $t_{c}$} & (days) & 7,28 \\
\hline
\end{tabular}

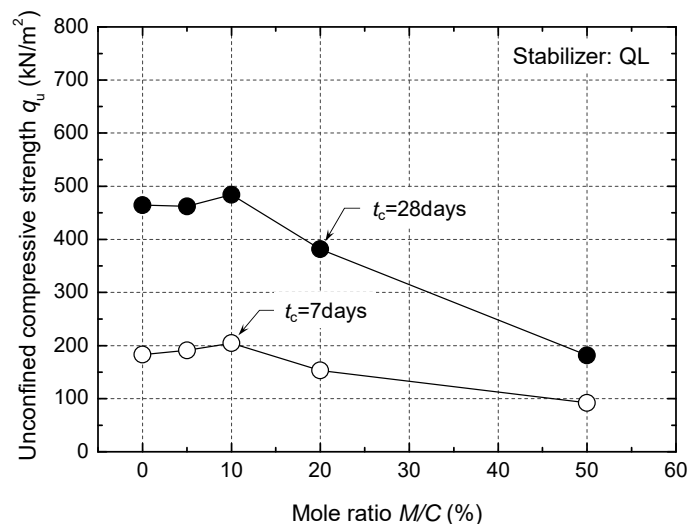

(a) 生石灰 (QL)

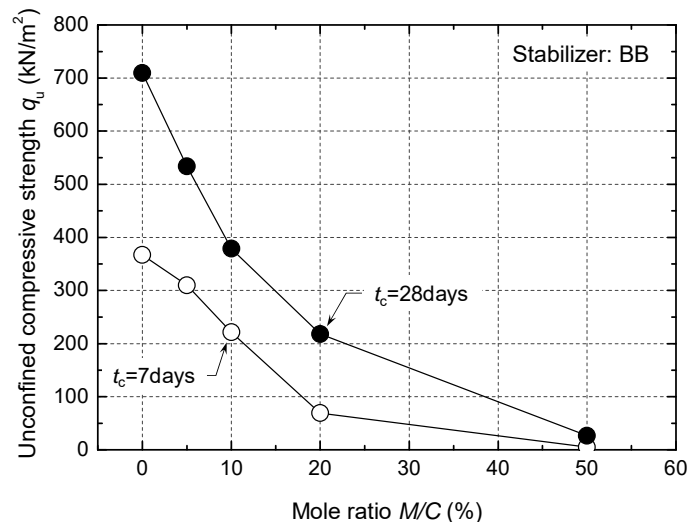

(b) 高炉セメントB種 (BB)

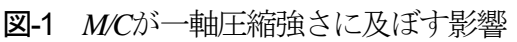

28日養生供試体の方が一軸圧縮強さが大きく，材齢とと もにその強度が増加している．固化材にQLを用いた場 合，養生期間にかかわらず， $M / C=10 \%$ まで若干の強度増 加が確認できるが，その後は $M / C の$ 増加に伴って強度低 下している，一方，固化材にBBを用いた場合， $M / C$ が増 加すると大きく強度低下しており，QL処理土のときに 認められた強度増加は確認できなかった。

得られた一軸圧縮強さを各実験ケースにおける $M / C=0 \%$ のときの一軸圧縮強さ $q_{\mathrm{u}} M C=-\%$ で除した值を正規 化一軸圧縮強さと定義する. その正規化一軸圧縮強さと $M / C の$ 関係を図-2に示す．それぞれの固化材の正規化一 軸圧縮強さは養生期間による差異は認められず，同程度

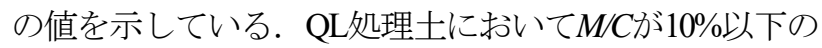
範囲で確認された強度増加率は $M / C=0 \%$ のときの $0 \sim 10 \%$

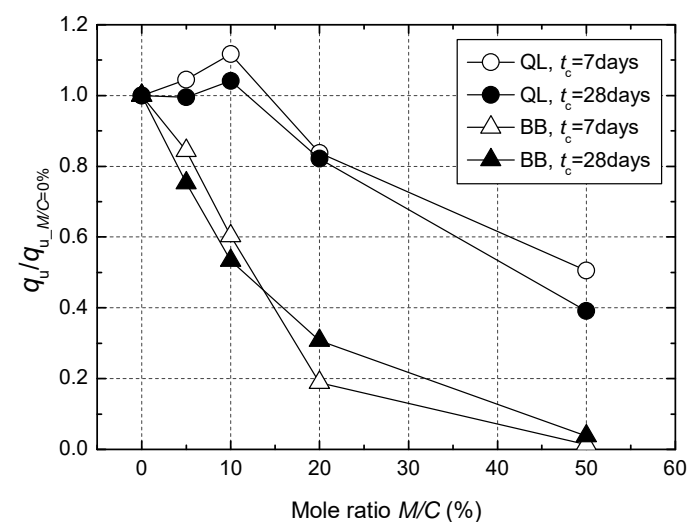

図-2 正規化一軸圧縮強さと $M / C$ の関係

程度であり，それ以上の範囲では強度低下している，例 えば $M / C=50 \%$ のとざは $M / C=0 \%$ のさの $50 \%$ ，もしく はそれ以下の一軸圧縮強さとなっている。一方BB処理 土では，M/Cが増加すると著しく強度が低下していき， $M / C=50 \%$ に至ると $M / C=0 \%$ のときの $5 \%$ 以下の強度を示し た. このことから，固化材とその添加量によって傾向と 程度は異なるものの固化処理土中のMg塩濃度が増加す ると一軸圧縮強さが減少寸ることが明らかとなった。こ れは，式(2)で示したように， $\mathrm{MgSO}_{4}$ との反応によって $\mathrm{Ca}(\mathrm{OH})$ 五失われたことに起因して, pHの低下が生じ, セメントの水和反応やポゾラン反応が抑制されたためと 考えられる. 固化材にQLを用いた場合，M/Cが10\%以下 の範囲で強度増加したことやBB処理土と比較して $M / C の$ 増加に対する強度低下が著しくないことの原因について は，表-2に示したように，QLはBBよりも $\mathrm{CaO}$ 含有率が

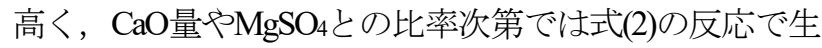
成された水酸化マグネシウム $\left(\mathrm{Mg}(\mathrm{OH})_{2}\right)$ や硫酸カルシ ウム2水和物 $\left(\mathrm{CaSO}_{4} ・ 2 \mathrm{H}_{2} \mathrm{O}\right)$ がセメンテーション効果 を発揮した可能性などが考えられるが，その詳細につい ては明らかではない。

\section{4. 海水環境下におけるマグネシウム塩を含有す る固化処理土の劣化速度}

\section{（1） 実験方法}

\section{a) 海水環境を想定した劣化促進実験}

固化処理土の劣化現象を引き起こす海水中の主な成分 は $\mathrm{MgCl}_{2}$ と $\mathrm{MgSO}_{4}$ であり, 式(1), (2)に示した化学反応を起 こす，本実験では，短期間で劣化速度を評価することを 目的に，海水の代用としてMg塩濃度を高く調整した水 溶液（以下，単に水溶液）を使用した。 そのため，水溶 液の濃度調整には，溶解度が高い塩化マグネシウムを選 択した. 水溶液は, 塩化マグネシウム6水和物 $\left(\mathrm{MgCl}_{2}\right.$ ・ $\left.6 \mathrm{H}_{2} \mathrm{O}\right)$ の試薬をイオン交換水に溶解させ，有明海の海 水の $\mathrm{Mg}^{2+}$ 濃度（0.938g/L）のの25倍の $23.5 \mathrm{~g} / \mathrm{L}$ となるように 


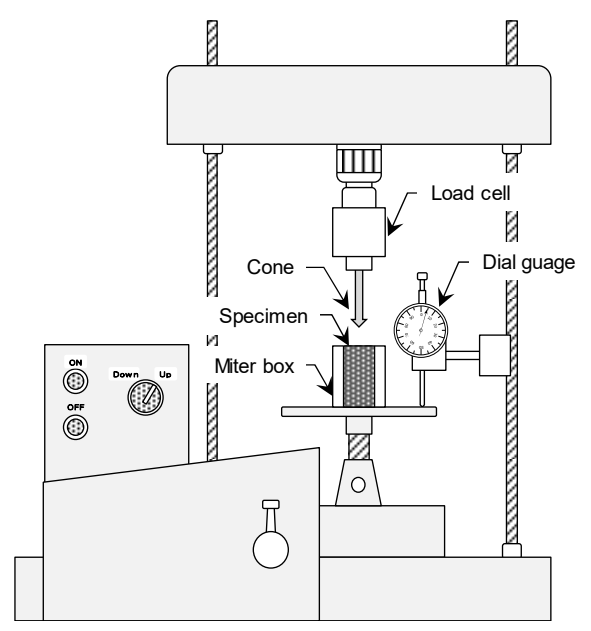

図-3 貫入試験機

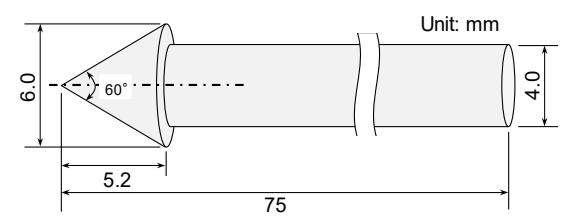

図-4＼cjkstart実験に用いたコーン

した. 著者らは既往の研究において, 海水浸漬したセメ ント処理土の劣化の進行速度は接触する海水中の $\mathrm{Mg}^{2+}$ 濃 度の平方根に比例することを明らかにしている ${ }^{10}$. その ため, 本実験で用いた水溶液は有明海の海水の5倍程度 の劣化促進効果を持つと考えられる.

28 日間養生した各 $M / C の \mathrm{QL}, \mathrm{BB}$ 処理土供試体を以下の 手順で水溶液に浸漬させた。 まず, 各実験ケースで供試 体を 5 本ずつ用意し，劣化の進行を一次元方向に制限す るため, 供試体の側面と下面をパラフィルムで覆った後 にゴムスリーブを被せ，上面のみを開放した状態とした. そして, 水溶液を投入したポリエチレン製の容器内に静 置した. このとき, 水溶液の量は供試体1本に対して1L とした．浸漬期間は0,4,9,16,25,36日に設定し，水溶液の 交換を 1 週間に1度実施した。 また，浸漬期間中は水温が $20 \pm 1{ }^{\circ} \mathrm{Cを}$ 保つように空調を調節した。

b) コーン貫入試験

水溶液に浸漬した供試体は開放面である上部から下方 に向かって劣化が進行する．そこで，供試体の劣化した 範囲を調べるために，小型のコーンを用いた貫入試験を 実施した．試験は以下のようにして行った．所定の期間 浸漬した供試体を取り出し，取り付けていたゴムスリー ブとパラフィルムを供試体が乱れないように外した。 そ の後，マイターボックスを取り付け，ステンレス製のバ ンドで固定して直径 $6.0 \mathrm{~mm}$ ，先端角度 $60^{\circ}$ の小型のコーン を $3 \mathrm{~mm} / \mathrm{min}$ の速度で供試体の上面（水溶液との接触面） から50〜70 mm程度貫入した．このとき，貫入抵抗と深 度をロードセルと変位計で毎秒測定した. 使用した貫入 試験機および用いたコーンの模式図を図-3,4に示す.

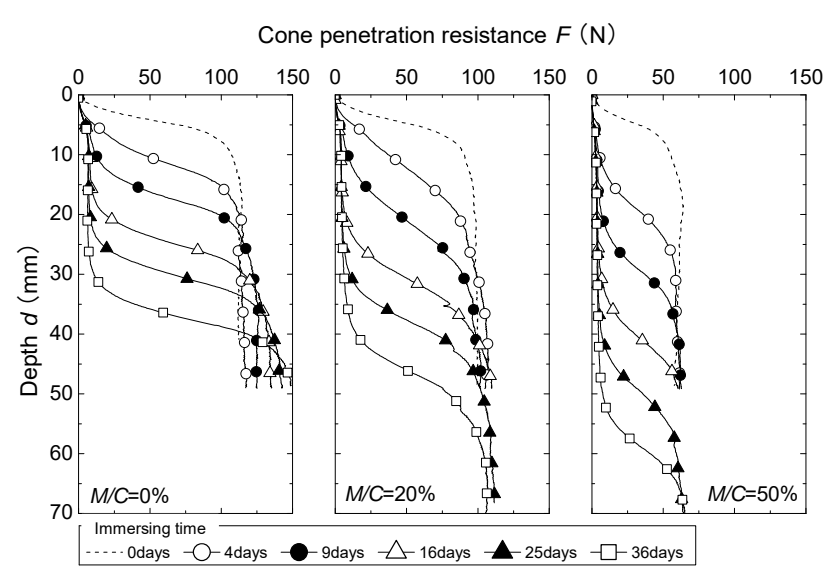

(a) 生石灰 (QL)

Cone penetration resistance $F(\mathrm{~N})$

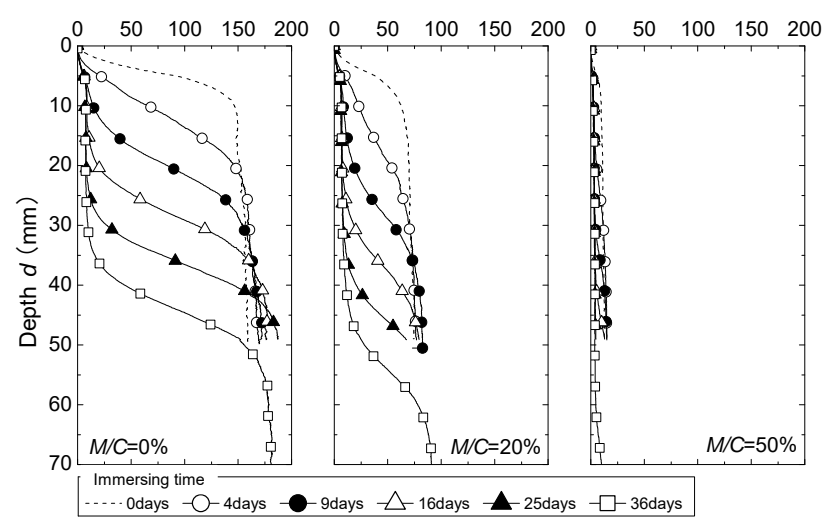

(b) 高炉セメントB種 (BB)

図-5 貫入抵抗の深度分布 $(M / C=0,20,50 \%)$

\section{(2) 実験結果}

\section{a) 貫入抵抗の深度分布}

コーン貫入試験結果の一例として $M / C=0,20,50 \%$ QL, BB処理土の貫入抵抗の深度分布を図-5に示寸. 固化材 の種類や $M / C$ によらず，浸漬前（浸漬 0 日）の供試体は 深度約 $10 \mathrm{~mm}$ まで貫入抵抗值が急激に増加し，それ以深 ではほぼ一定值を示している，深部における貫入抵抗值 は $M / C か ゙$ 高いときほど小さくなっており，その傾向はと くに固化材にBBを用いた場合に顕著である。このこと は, 先述したようにBB処理土はM/Cの増加にともなって 大きく強度低下したことと符合する. 所定の期間水溶液 に浸漬させた供試体は，貫入の初期段階で浸漬前に比べ てかなり小さな貫入抵抗を示寸範囲が認められ，その範 囲は浸漬期間とともに拡大している. また, それ以深で は浸漬期間によらずほぼ同様の変化傾向を示し, 最終的 に示寸抵抗值は浸漬前と同程度の值に収束している.

\section{b) 固化処理土中のマグネシウム塩が劣化速度に及ぼす 影響}

著者らの提案する方法11に基づいて，水溶液に浸漬し た供試体において力学的に劣化した範囲を劣化深度とし て定量した. 劣化深度の経時変化を図-6に示寸. QL処 理土, $\mathrm{BB}$ 処理土ともに劣化深度は浸漬期間が経過する 


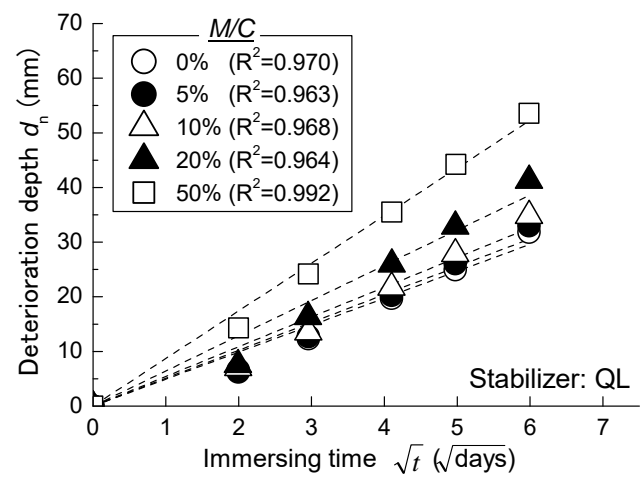

(a) 生石灰 (QL)

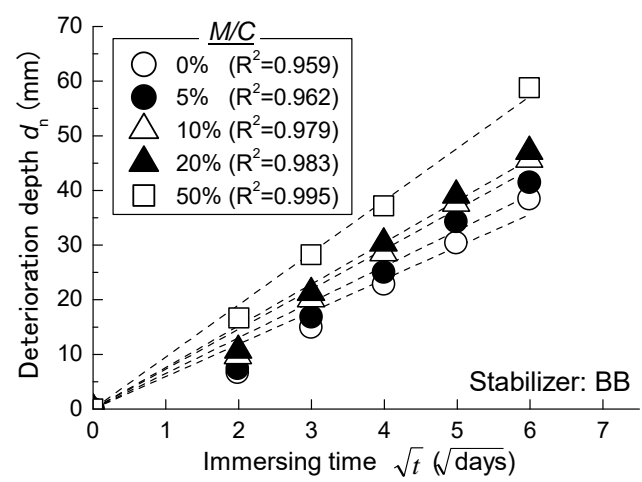

(b) 高炉セメントB種（BB）

図-6 劣化深度の経時変化

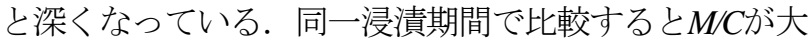
きい場合ほど劣化深度が深いことも確認できる、M/Cが $0 \%$ と $50 \%$ のときの浸漬 36 日供試体の劣化深度 $d_{36}$ を比較す るとQLの場合は31.82, 53.55mm，BBの場合は38.51，

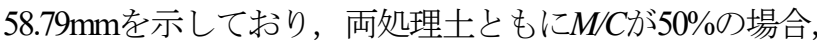
$0 \%$ に比べて劣化深度が 1.5 倍以上深くなっている.

著者らは，固化材に普通ポルトランドセメント（OPC） を用いた場合，劣化深度は海水との接触期間の平方根に 比例して拡大することを報告している10)。図中の破線は, 本実験における劣化深度を式(6)で近似したものである.

$$
d_{\mathrm{n}}=A \sqrt{t}
$$

ここに， $d_{\mathrm{n}}$ は劣化深度 $(\mathrm{mm}) ， A$ は劣化速度係数 （mm/ $\sqrt{\text { days }}) ， t$ は浸漬期間（days）を表す.

近似直線と実験值の乘離は小さく，決定係数 $\mathrm{R}^{2}$ む1 1 亿 近い值を示しており，非常によく近似できている。この ことから，固化材にQL, BBを用いた場合もOPCと同様に 浸漬期間の平方根に比例して力学的劣化領域が拡大する ことが明らかとなった。

先の実験結果から抽出した劣化速度係数 $A$ と $M / C の$ 関 係を図-7に示す. QL, BB処理土の両者とも $M / C か ゙$ 増加す るとAの值も大きくなり, 劣化速度が速くなることが認 められた．同じM/Cのときでは，Aの值はBB処理土の方 がQL処理土よりも大きくなっている．また，先述した 一軸圧縮試験の結果では，QL処理土はM/Cが10\%以下で

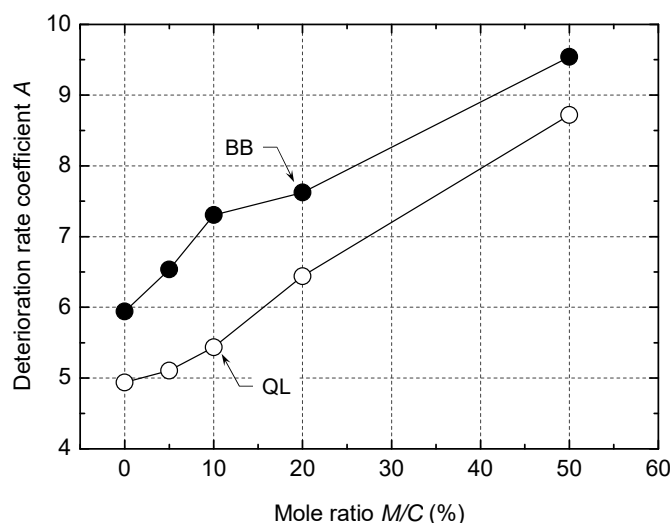

図-7 劣化速度係数と $M / C の$ 関係

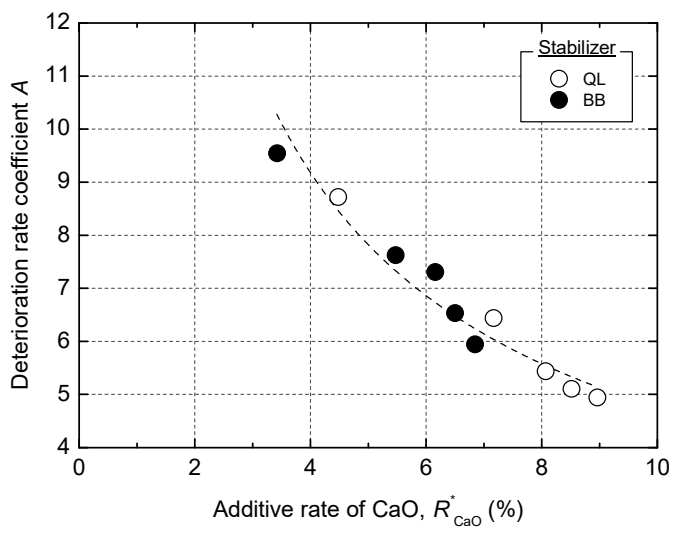

図-8 劣化速度係数と実質 $\mathrm{CaO}$ 添加率の関係

僅かに強度増加が確認されたが，その範囲においてもA の值はM/Cとともに高くなる傾向が認められる。したが って，Mg塩によって強度増加が生じる場合においても 劣化速度は速くなるものと考えられる。

c) マグネシウム塩を含む固化処理土の劣化速度の評価 指標

つぎに，試料土に添加した $\mathrm{CaO} と \mathrm{MgSO}_{4}$ に着目して固 化材の種類を問わず，劣化速度を評価できる簡易なパラ メータの導出を試みた. 式(1), (3)に示したように，土中 の $\mathrm{MgSO}_{4}$ は固化材に含まれるCaOを固化にほとんど寄与 しない形態へと変化させる. すなわち, 固化処理土の力 学的劣化の進行速度は添加した固化材に含まれる $\mathrm{CaO}$ 量 とそれを固化に寄与しない物質へと変化させる $\mathrm{Mg}$ 塩と の比率によって定まるものと考え, 試料土の乾燥質量に 対する $\mathrm{MgSO}_{4}$ と反応せずに残存した $\mathrm{CaO}$ 量を実質 $\mathrm{CaO}$ 添 加率 $R_{\mathrm{CaO}}^{*}$ と定義した. $R_{\mathrm{CaO}}^{*}$ は式(7)によって求められる.

$$
R^{*}{ }_{\mathrm{CaO}}=\frac{\alpha \cdot C_{\mathrm{CaO}}(1-M / C)}{\rho_{t} /(1+w / 100)}
$$

ここに， $R_{\mathrm{CaO}}^{*}$ は実質 $\mathrm{CaO}$ 添加率（\%)， $\alpha$ は固化材添加量 $\left(\mathrm{kg} / \mathrm{m}^{3}\right) ， C_{\mathrm{CaO}}$ は固化材の $\mathrm{CaO}$ 含有率 $(\%), M / C$ は試料 土に添加した $\mathrm{CaO}$ に対する $\mathrm{MgSO}_{4}$ のモル比， $\rho$ は試料土 の湿潤密度 $\left(\mathrm{kg} / \mathrm{m}^{3}\right), w$ は試料土の含水比（\%) を表す。

劣化速度係数 $A$ と実質 $\mathrm{CaO}$ 添加率 $R_{\mathrm{CaO}}^{*}$ の関係を図-8に 示す. 固化材によらず， $R^{*}$ CaOが増加するとAの值は一様 
に減少する傾向が確認できる，これは，海水環境下にお ける固化処理土の劣化速度は処理土中に残存した $\mathrm{CaO}$ 量 の影響が支配的であり，固化材の違いによる水和生成物 の差異やそれに起因した構造の変化の影響は小さいこと を示寸ものである. なお，本実験では，一般的な海水よ りもMg濃度を著しく高く設定している，そのため， Mg 濃度などの浸漬条件，さらには母材となる試料の土質が 異なる場合では，Aの值も同様に異なることに留意する 必要がある.

\section{5. 結論}

生石灰と高炉セメントB種を固化材としたマグネシウ 八塩を含む固化処理土の強度発現および海水環境下での 劣化速度に関する基礎的な検討を行った. 本研究より得 られた主な知見は以下のとおりである.

(1) 固化処理土に含まれるマグネシウム塩濃度の増 加に伴って一軸圧縮強さは減少する。 また, 固 化材に生石灰を用いた場合, 若干強度が増加す るケースも確認された。

(2) 生石灰, 高炉セメントB種を固化材として用い た処理土の劣化深度は水溶液との接触期間の平 方根に比例して拡大寸る.

(3) 土中のマグネシウム塩濃度が高いときほど，海 水環境下における石灰・セメント処理土の劣化 速度が速くなる。 また, 劣化速度は固化材の種 類にかかわらず，本研究で提案した実質 $\mathrm{CaO}$ 添 加率 $R^{*}$ calによって評価できる.

謝辞 : 本研究において, 山口大学卒業生の星山尚登氏に 多大な協力をいただいた。 ここに記して謝意を表する.

\section{参考文献}

1) Zhu, W., Chiu, C. F., Zhang, C.-L. and Zeng, D.-L.: Effect of humic acid on the behavior of solidified dredged material, Canadian Geotechnical Journal, Vol. 46, No. 9, pp. 10931099, 2009.

2）（社）セメント協会 セメント系固化材技術専門委員 会：火山灰質粘性土のセメント改良体における強度 発現に関する検討《アロフェンの影響について》, セメント・コンクリート, No.780, pp.3-8, 2012.

3) 西形達明, 山田哲司, 西田一彦, 松田豊 : 酸化マグ ネシウムの地盤改良への適用について, 土と基礎, Vol.54. No.7, pp.19-21, 2006.

4) 大山将, 奥村正孝, 保賀康史, 西村良平 : 酸化マグ ネシウム系材料による固化・不溶化技術, 地盤工学 会誌, Vol.57, No.7,pp.20-23, 2009.

5) 田口岳志, 日野剛徳, 西野伸幸, 三浦有規子, 柴錦 春 : 2 段階処理施工パターンにおけるハイブリット式 安定処理土の強度 - 間隙構造 - 溶出特性, 第 44 回地 盤工学研究発表会, pp.619-620, 2009.

6) 原弘行, 未次大輔, 林重徳, 松田博: 海水に曝露し たセメント処理土の劣化機構に関する基礎的研究, 土木学会論文集 C（地圈工学）, Vol.69, No.4, pp.469479, 2013.

7) 吉田彰: 海水マグネシア, Journal of the Society of Inorganic Materials, Japan, Vol. 9, No. 300, pp. 294-303, 2002.

8) Buenfeld, N. R. and Newman, J. B.: The permeability of concrete in a marine environment, Magazine of Concrete Research, Vol. 36, No. 127, pp. 67-80, 1984.

9) 日本石灰協会 : 石灰安定処理工法, pp.1-23, 2006.

10) 原弘行, 末次大輔, 林重徳, 松田博 : 海水環境下に おけるセメント処理した有明粘土の劣化の進行に関 する検討，材料, Vol.63, No.1, pp.49-54, 2014.

11) 原弘行, 未次大輔, 松田博: 海水曝露によって劣化 した石灰処理土の間隙径分布と圧密特性, 土木学会 論文集 C（地圈工学），Vol.71, No.3,pp.177-190, 2015.

(2016. 4.7 受付)

\section{MECHANICAL PROPERTY AND DETERIORATION RATE UNDER SEAWATER OF LIME AND CEMENT STABILIZED CLAY CONTAINING MAGNESIUM SALTS}

\section{Hiroyuki HARA, Daisuke SUETSUGU, Hiroshi MATSUDA and Takeshi KAMEI}

Solidification of clayey soil by adding quick lime or cement materials may be inhibited due to the soil properties such as types of clay minerals, water quality of porewater. In this study, in order to investigate the mechanical property of lime and cement stabilized clay containing magnesium salts, unconfined compression test was conducted. Subsequently, accelerated deterioration test which was simulated seawater environment was performed to investigate the effect of concentration of magnesium salts on deterioration behavior of stabilized clay. As a result, it is verified that magnesium salts have functions to decrease the strength and accelerate the progression of deterioration of stabilized clay. Additionally, a new parameter that can evaluate the deterioration rate of stabilized soil containing magnesium salts regardless of stabilizer types was proposed. 